\title{
nombalina
}

(8)

\section{Lean Maintenance}

Autor(es): Inácio, Bruno

Imprensa da Universidade de Coimbra; Faculdade de Ciências e

Publicado por: Tecnologia da Universidade de Coimbra, Departamento de Engenharia Mecânica

URL persistente:

URI:http://hdl.handle.net/10316.2/33331

DOI:

DOI:http://dx.doi.org/10.14195/978-972-8954-42-0_19

Accessed : $\quad$ 26-Apr-2023 09:12:33

A navegação consulta e descarregamento dos títulos inseridos nas Bibliotecas Digitais UC Digitalis, UC Pombalina e UC Impactum, pressupõem a aceitação plena e sem reservas dos Termos e Condições de Uso destas Bibliotecas Digitais, disponíveis em https://digitalis.uc.pt/pt-pt/termos.

Conforme exposto nos referidos Termos e Condições de Uso, o descarregamento de títulos de acesso restrito requer uma licença válida de autorização devendo o utilizador aceder ao(s) documento(s) a partir de um endereço de IP da instituição detentora da supramencionada licença.

Ao utilizador é apenas permitido o descarregamento para uso pessoal, pelo que o emprego do(s) título(s) descarregado(s) para outro fim, designadamente comercial, carece de autorização do respetivo autor ou editor da obra.

Na medida em que todas as obras da UC Digitalis se encontram protegidas pelo Código do Direito de Autor e Direitos Conexos e demais legislação aplicável, toda a cópia, parcial ou total, deste documento, nos casos em que é legalmente admitida, deverá conter ou fazer-se acompanhar por este aviso. 


\title{
Lean Maintenance
}

\author{
Bruno Inácio \\ bruno.inacio@profitabilityengineers.pt \\ ProfitAbility Engineers, Lda. \\ Lisbon, Portugal
}

\begin{abstract}
Lean implementation requires full organizational involvement, and success often depends on the details. One of those details is, without a doubt, the "wellbeing" of process equipment.

In order to assure a levelled production flow, all key process elements, such as personnel, materials and machines, need to maintain high availability. Availability, performance and fabrication quality (which can all be traced back to the process equipment in direct or indirect ways) becomes essential for predictable and reliable adherence to scheduling and customer expectations.
\end{abstract}

Without adequate maintenance practices, such as TPM (Total Productive Maintenance), the process will most likely fall short of the overwhelming demands placed on it by JIT (Just In Time) and "zero stock" philosophies.

Methodologies such as SMED (Single Minute Exchange of Dies), Heijunka (levelled production scheduling) and Kanban (JIT pull-flow production) all depend on equipment uptime and performance. Deviations cause, as would be expected, wastes in the form of delays, defects and inventory.

Maintenance is therefore a cornerstone for achieving the so desired "perfect process" level. We can, of course, ask: What is a perfect process? It is a process without "muda" (Japanese word for "waste"), in which each step adds value, is perfectly capable, is available and is exactly adequate for the needs. All the steps are linked by continuous synchronous flow, pulled by customer demand and levelled.

Keywords - Lean, SMED, SMM, Waste Reduction, TPM.

\section{INTRODUCTION}

Lean Production - what is it?

- "A production philosophy which reduces the time between order and delivery, through the systematic reduction of waste (activities that do not add value)" [1].

- "A systematic approach to identify and eliminate waste, through continuous improvement, making products flow, whenever the customer requests, in the search for perfection" [2].

The goal is to promote competitiveness. This, in turn, can be defined as doing it better, cheaper and quicker than the competition.

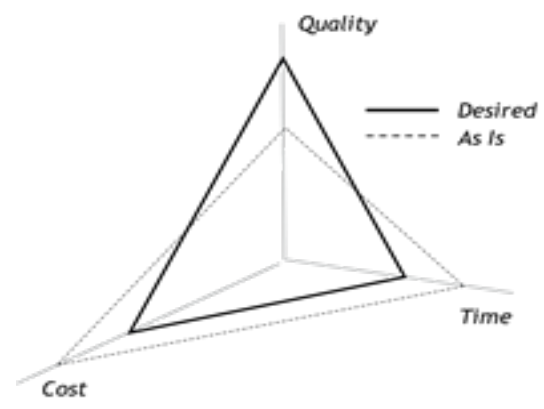

Fig. 1. The 3 vectors to improve in order to be competitive.

In this sense, the generalized objectives of Lean Production can be summarized as:

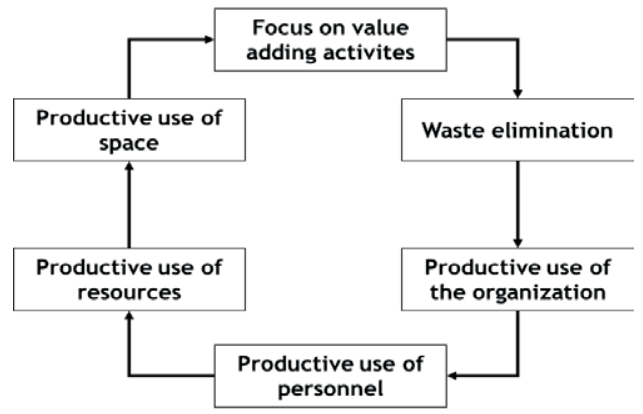

Fig. 2. The generalized Lean objectives.

It is precisely in the "productive use of resources" that the concept of Lean Maintenance finds it's framework, in other words, analyze and eliminate waste, improving continuously the maintenance activity.

But what of the waste? Any industrial activity can contain one or more of the following wastes:
1. Overproduction
2. Delays
3. Transport
4. Processing waste
5. Unnecessary inventory
6. Unnecessary movements
7. Product/service defects. ${ }^{[3]}$

Maintenance, an industrial activity, can naturally suffer from any of the abovementioned 7 wastes, but the Lean concept has 
gone further and references 8 specific wastes directly attributed to maintenance:

TABLE I. THE 8 WASTES IN MAINTENANCE [4]

\begin{tabular}{|c|c|c|}
\hline \multirow{2}{*}{$\mathbf{N}^{0}$} & \multicolumn{2}{|c|}{ The 8 wastes in maintenance } \\
\hline & Waste & Description \\
\hline 1 & $\begin{array}{l}\text { Equipment } \\
\text { malfunction }\end{array}$ & $\begin{array}{l}\text { Waste can occur due to loss of function or } \\
\text { deterioration of function (loss of } \\
\text { performance) }\end{array}$ \\
\hline 2 & Setups and tuning & $\begin{array}{l}\text { Downtime due to setups and process } \\
\text { adjustments, until the first conform } \\
\text { product is obtained. }\end{array}$ \\
\hline 3 & Component swap & $\begin{array}{l}\text { The need to stop the process to swap out a } \\
\text { cutting tool. }\end{array}$ \\
\hline 4 & Startup losses & $\begin{array}{l}\text { Waste generated when a process takes a } \\
\text { long time to stabilize, after a shutdown. }\end{array}$ \\
\hline 5 & Micro stoppages & $\begin{array}{l}\text { Short (often not recorded) downtime due } \\
\text { to a faulty sensor, a defective part that } \\
\text { blocks flow. }\end{array}$ \\
\hline 6 & Loss of speed & $\begin{array}{l}\text { Waste due to deviations between the } \\
\text { actual running speed and the planned } \\
\text { speed for the equipment. }\end{array}$ \\
\hline 7 & $\begin{array}{l}\text { Defects and } \\
\text { rework }\end{array}$ & $\begin{array}{l}\text { Delays and waste of resources due to } \\
\text { faulty product, which results from any } \\
\text { equipment deviation. }\end{array}$ \\
\hline 8 & Downtimes & $\begin{array}{l}\text { Losses associated with stopping } \\
\text { equipment in order to perform planned or } \\
\text { corrective maintenance. }\end{array}$ \\
\hline
\end{tabular}

II. LEAN MAINTENANCE

\section{A. The demands that Lean places on maintenance}

As stated in the abstract, a lean process requires process steps that add value, are capable and available. Bearing in mind that most process steps rely on equipment, the demands on the process are equally demands on the equipment. TPM has the objective of reducing breakdowns to zero, which improves the "bathtub" curve.

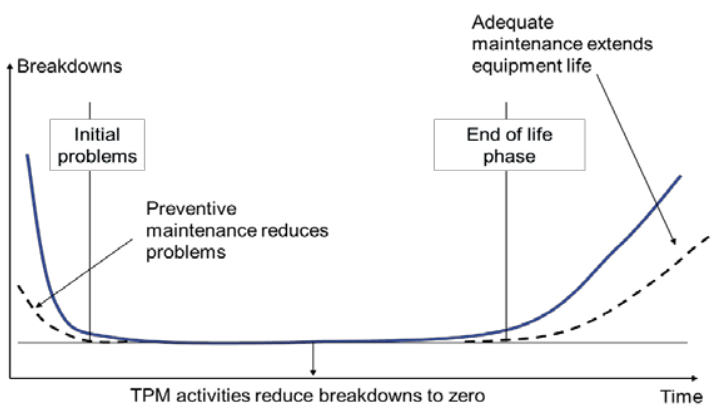

Fig. 3. The effect of TPM, [4]

\section{B. The 5 maintenances in Lean enterprises}

\section{Breakdown Maintenance (BM)}

The goal is to minimize the time wasted in stoppages due to breakdowns. Each simple breakdown should be solved in less than 10 minutes. This is often referred to as "Single Minute Maintenance".

\section{Preventive Maintenance (PM)}

Preventive maintenance refers to all tasks done to prevent breakdowns. Initial actions are based on the equipment manufacturer's recommendations, and as knowledge of the equipment and process needs improves, plans are adapted, with special attention not to "overservice" the equipment.

\section{Daily Maintenance (DM)}

Daily maintenance includes all the day-to-day maintenance activities, which are executed by the operators, such as cleaning, inspection, lubrication and tightening. In other words, this is TPM. Operators are obligated to request the aid of the maintenance personnel, whenever a symptom is detected which exceeds their training. Over time, maintenance personnel analyze the occurrences, and look for ways to simplify the repair work (based on the Single Minute Maintenance principle), so that it can be taught to the operator. The reason is simple: if the person who is already at the equipment can solve the problem, this is the best way to ensure that breakdown time will be minimal.

\section{Corrective Maintenance (CM)}

The need arises, from time to time, to take corrective actions on some equipment. After years of use, or due to some design flaw, a weakness in the equipment may arise, rendering it incapable or inadequate for the process needs. These weaknesses are therefore corrected, assuring that the equipment performs as needed. This is obviously done if the investment pays off, and as long as no compromise to product quality exists.

\section{Preventive Engineering (PE)}

The knowledge and experience of maintenance personnel is used, to specify equipment and/or tool needs prior to purchase. The goal is to prevent problems and the need for future corrections, in the equipment design phase. Also, clever changes to certain aspects of equipment design can make it much easier to swap parts in case of a breakdown, making it easier to reach the Single Minute Maintenance objective.

\section{The link between maintenance and productive mainteance} activities

TPM activities have a direct link with the planned maintenance, the core activity of the maintenance function. The image bellow shows the advantage of having TPM activities contribute to the various maintenance objectives.

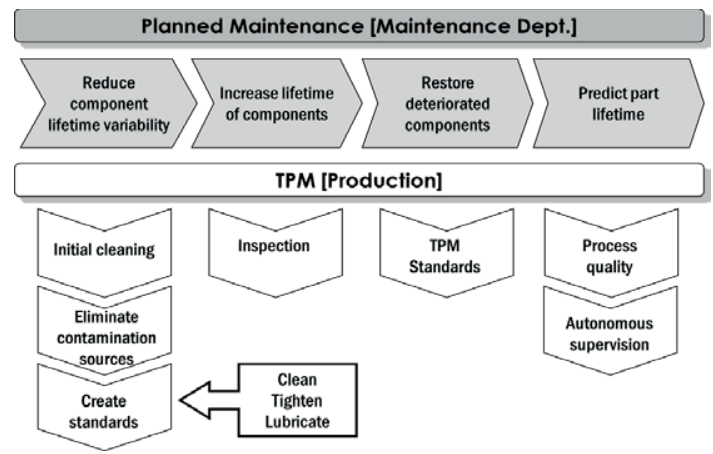

Fig. 4. TPM links to maintenance objectives, [4]

\section{A TPM standard example}

Figure 5 shows an example of a TPM plan template for a particular equipment, in this case, a plastic injection molding machine. It can be seen that visual aids have been created to assist the operator. These visual aids are physically placed on the equipment itself, making it very easy for the operator to identify what needs to be done, and with what frequency. Likewise, turning the TPM routine as simple and comprehensive as possible also facilitates the training of new personnel. 


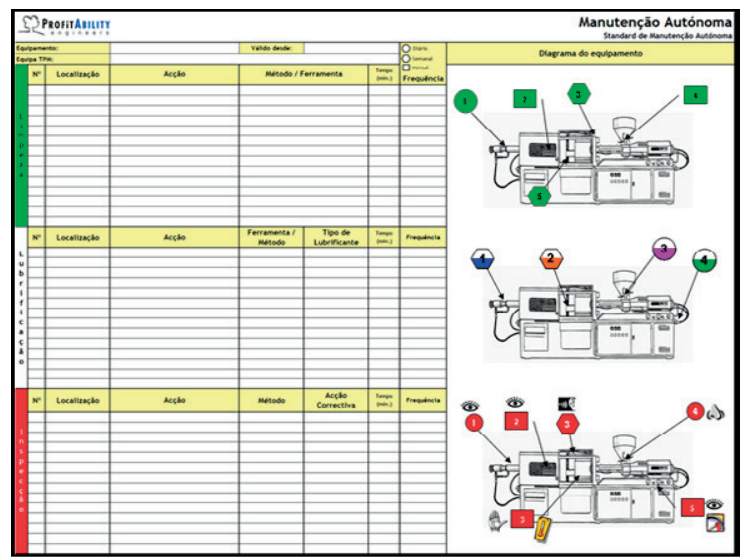

Fig. 5. Injection molding TPM template.

\section{E. Improving maintenance activities}

Many different lean tools can be applied to process improvement workgroups, but sometimes, keeping it simple makes the difference. A very simple 4 step method, adequate for involvement at the operator or technician level is the TWI "Job Methods" approach.[5]

The 4 step method can be summarized in Figure 6 .

\begin{tabular}{|c|c|}
\hline \multicolumn{2}{|c|}{$\begin{array}{c}\text { Step } 1 \text { : Operation Breakdown } \\
\text { List each and every detail }\end{array}$} \\
\hline $\begin{array}{l}\text { Step } 2 \\
\text { Question }\end{array}$ & $\begin{array}{l}\text { Step } 3 \\
\text { Improve }\end{array}$ \\
\hline $\begin{array}{l}\text { Why? } \\
\text { What? }\end{array}$ & Eliminate! \\
\hline $\begin{array}{l}\text { Where? } \\
\text { When? }\end{array}$ & Combine! \\
\hline Who? & Reorganize! \\
\hline How? & Simplify! \\
\hline
\end{tabular}

Fig. 6. Job Methods 4 steps [5]

Kaizen workshops/workgroups, using the 11-step method, are also very effective in analyzing and improving any activity, and are typically used to the reduction of waste at a process level, not at a specific operation. The Job Methods approach is typically preferential for shop floor workgroups.

\section{CASE STUDY - SMED APPLIED TO THE SUBSTITUTION OF AN ELECTRIC MOTOR}

\section{$F$. The SMED method in summary [6]}

The purpose of SMED (Single Minute Exchange of Dies) is to execute setup activities in processes such as stamping, injection molding or any other situation in which a process needs to be stopped to allow for setup of a different product. It is evident that it is of great interest to a process to minimize this time, with gains in terms of batch sizes, inventory and flexibility to customer changes. The improvement method is summarized in Figure 7, in which external activities refer to all activities that can be done while the process is still running (preparation) or after the process has initiated (cleanup, putting tools away) and internal activities refer to all activities that must be done with the equipment stopped.

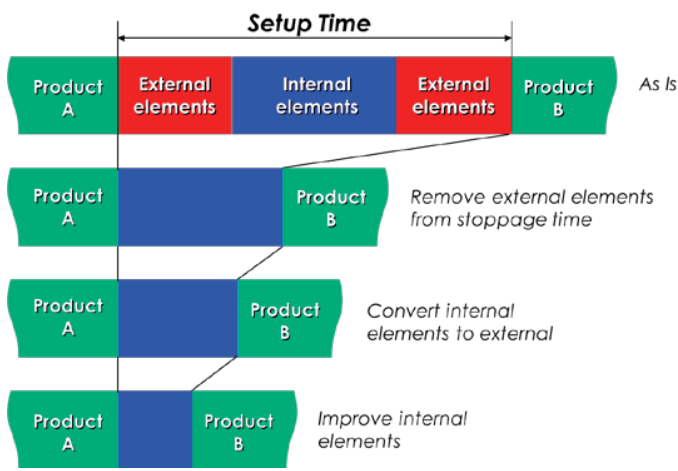

Fig. 7. SMED method summary.

\section{G. SMED to SMM application}

\section{Planned repair}

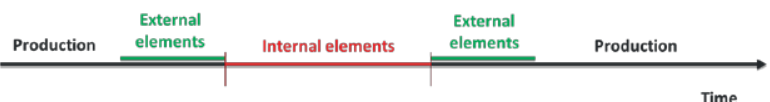

\section{Breakdown}

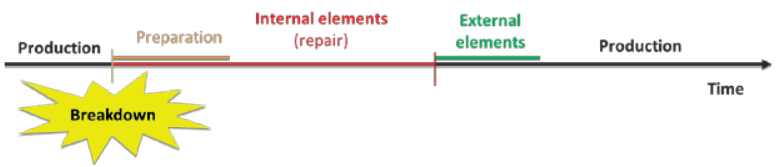

Fig. 8. SMM application logic

As Figure 8 shows, in the case of a maintenance activity, there is a direct analogy to the SMED method, when we are in the situation of a planned repair. But in the case of a breakdown, all preparation activities that would otherwise be done while the equipment is still running are now internal activities, since the equipment has broken down. In both of these situations, the SMED method can be applied, with obvious gains.

\section{H. Setup for documentation}

The chosen equipment was an electric motor, which needs to be removed, substituted, and the new motor aligned. Since these type of activities take some time and, fortunately, seldom happen, it is not practical to take notes about the process steps, especially when multiple operators are involved. In this case, two mechanical and one electrical maintenance technicians were involved. The best approach is to document the work with video, and in this case three cameras were set up, one of them with a wide angle of the operation, one of them filming close-ups from $180^{\circ}$, and the third was free to move around to capture hand details and accompany any one of the technicians that for some reason might need to walk away from the spot.

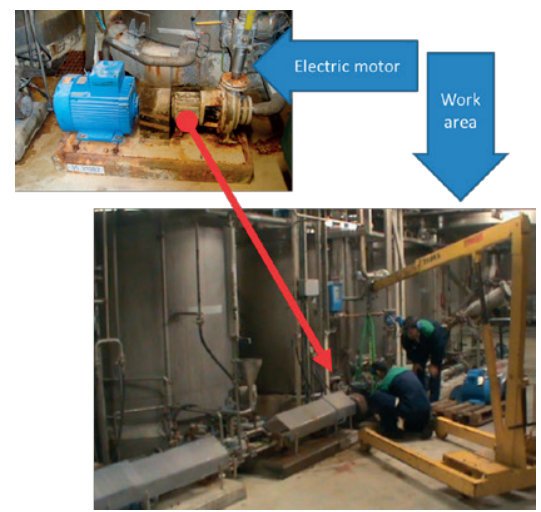

Fig. 9. Work area and equipment. 


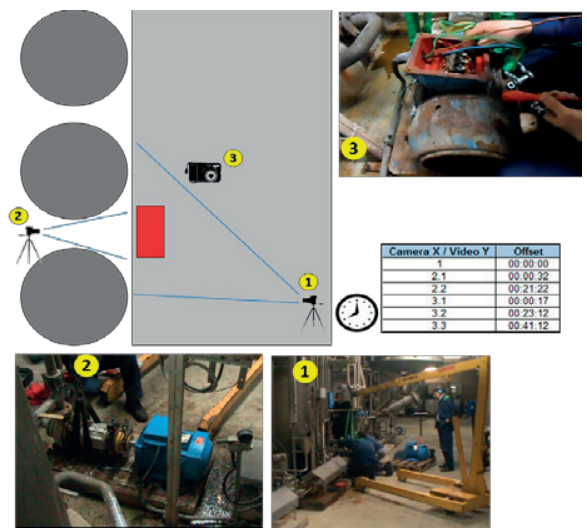

Fig. 10. Camera setup.

As shown in Figure 10, camera 1 was defined as the "master clock" and the other videos were then offset to assure that, referencing the appropriate camera, the correct time would be recorded for each detail.

After this, the technicians executed the setup as they would normally do.

\section{Analysis}

The team was then assembled in a meeting room to breakdown the various videos and to register the operation steps and times. This is the first analysis of this operation, therefore not every micro detail is recorded, the main steps are identified. It is of the utmost importance that the technicians filmed are also present in these work sessions, since they can clarify exactly what they are doing and why, and also to promote multi-level involvement and teamwork. It is also very important for the executers to be present during the discussion and brainstorming of improvements, since any decided change will directly impact on their work. They therefore have an important role in deciding what gets changed.

The work sessions yield a summary table with a quantitative indication of the times, and a Gantt chart, showing the critical path of the operation. The critical path, in this case, is identified as the sequence o activities which increment "stopwatch time". There are a number of activities which, regardless of the fact that they count as work time, occur simultaneously with critical path activities, therefore they are of second priority, since an improvement done on them will have no impact in the actual time that the equipment is stopped.
TABLE II. OPERATION ELEMENTS AND THEIR TIMES. RED BARS SHOW EXTERNAL ACTIVITIES, WHILE BLUE SHOW INTERNAL. THE REDDISH LINES SHOW STEPS THAT CAN BE ELIMINATED, REGARDLESS OF EXTERNAL OR INTERNAL.

\begin{tabular}{|c|c|c|c|c|c|c|}
\hline \begin{tabular}{l|l} 
No \\
Sea.
\end{tabular} & $\operatorname{sen} \mid=$ & $8 T^{7}$ & & 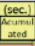 & $\%$ & Time chart \\
\hline 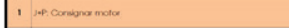 & $\cdots$ & $-\infty$ & - & -- & -1 & $\square$ \\
\hline 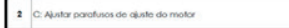 & $=-$. & - & - & $-\infty$ & $=1$ & $\square$ \\
\hline 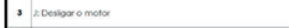 & $=-\infty$ & $\ldots$ & $=$ & $\cdots$ & $=1$ & $\square$ \\
\hline 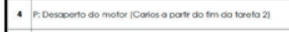 & $-\infty$ & $-\infty$ & $\cdots$ & $m-$ & $=$ & $\square$ \\
\hline 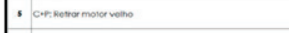 & $\cdots$ & --- & $-\infty$ & $=$ & -1 & I \\
\hline 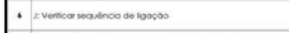 & $\ldots$ & - & - & - & -1 & 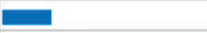 \\
\hline 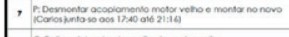 & $-\infty$ & - & - & - & -1 & 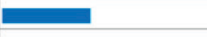 \\
\hline 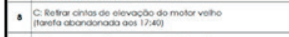 & $-\infty$ & $-\infty-$ & $=$ & $-\infty$ & $\cdot 1$ & 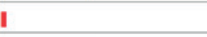 \\
\hline 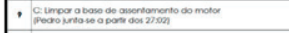 & $\ldots$ & -- & $\cdots$ & $-\infty$ & - & 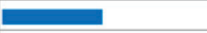 \\
\hline 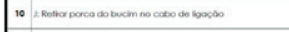 & $-\infty$ & $=-$ & $\cdots$ & $+a$ & $\cdot-1$ & $\mathbf{a}$ \\
\hline 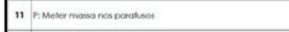 & $-\infty$. & $-\infty$ & $+\infty$ & $-m$ & $\cdot$ & $\square$ \\
\hline 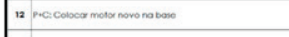 & $-\cdots$ & -- & $-\infty$ & -- & $\cdot 1$ & a \\
\hline 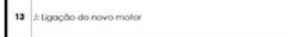 & $-\cdots$ & $-\infty$ & $\cdots$ & $-\infty+\infty$ & -1 & 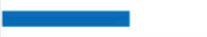 \\
\hline 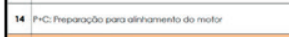 & 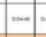 & $\ldots$ & $=$ & $=-\infty$ & -1 & 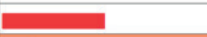 \\
\hline 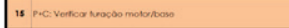 & - & $\ldots-\cdots$ & $-=$ & $-\infty$ & -1 & $\square$ \\
\hline 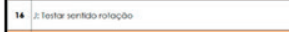 & $--\infty$ & $-\infty$ & $-\infty$ & $-\infty$ & -1 & 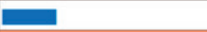 \\
\hline 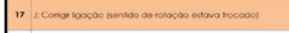 & $-\infty$ & -- & - & $-\infty$ & -1 & $\square$ \\
\hline 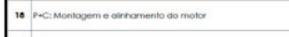 & $-\infty$ & - & $-\infty$ & -- & -1 & 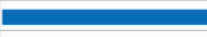 \\
\hline 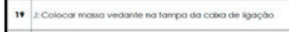 & $-\infty$ & $-\infty=$ & - & $\cdots$ & -1 & 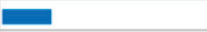 \\
\hline 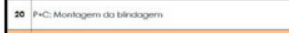 & $=$ & $=-$ & - & $\ldots$ & -1 & 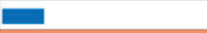 \\
\hline 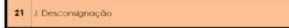 & $\cdots$ & $-\infty$ & -- & $\cdots$ & - & $\square$ \\
\hline
\end{tabular}

TABLE 3. GANTT CHART SHOWING CRITICAL PATH STEPS IN RED, AND SIMULTANEOUS STEPS IN BLUE.

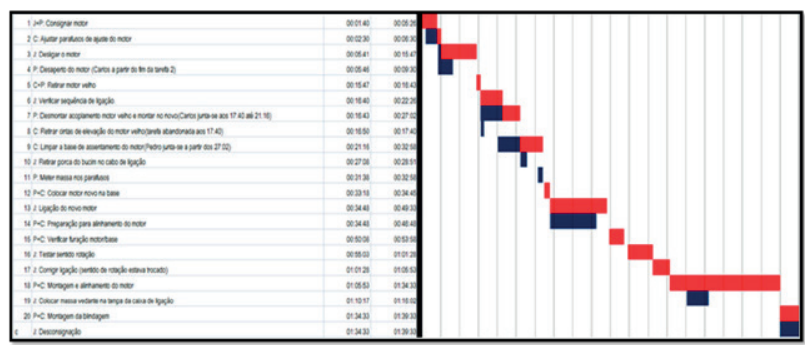

J. Results obtained

Based on the analysis mentioned above, the team decided upon actions and implemented the corresponding action plan. It is normal that, in the first iteration of these methods, simple aspects are optimized, such as:

- Work reorganization: Technicians wait for one to finish work before they start theirs, and when asked what could be be doing during this time, they tend to identify that they could prepare the following task, or prepare a later task

- Conversion to external tasks: The motor's coupling had to be removed and inserted into the new motor. With a second coupling, which is often available, this task can be converted to external.

- Improving tools: Simple hand wrenches were being used. These were substituted by a ratchet wrench, with significant reduction in time.

A new substitution was done, for the sake of validating the improvements, and new videos and analysis were done. A brief summary of the obtained results are shown in Table 4, where it is possible to see that $38 \%$ of "stopwatch time" reduction was obtained. This represents a reduction of approximately 38 minutes in downtime, with the first iteration of the SMM method on this operation. 
TABLE IV. SMM RESULTS SUMMARY.

\begin{tabular}{|l|l|l|c|c|}
\hline \multicolumn{5}{|c|}{ SMM summary table (first improvement iteration) } \\
\hline & Before & After & \multicolumn{1}{|c|}{ VARIATION } \\
\hline Time & [min] & [min] & Time (min.) & \% improved \\
\hline $\begin{array}{c}\text { Real stoppage } \\
\text { time }\end{array}$ & 99,55 & 61,5 & 38,05 & $38 \%$ \\
\hline $\begin{array}{c}\text { Work content } \\
\text { Activity } \\
\text { overlapping } \\
\text { (simultenous) }\end{array}$ & 141,48 & 77,53 & 63,95 & $45 \%$ \\
\hline
\end{tabular}

We can also see that there was a reduction of $45 \%$ in work content, which means that the improvements did eliminate a very significant part of the time spent doing work. This is important, because it means that the stoppage time was not reduced by $38 \%$ just by reorganization of external tasks, but there was significant elimination and simplification of work. It is possible to see a reduction of $9 \%$ in terms of work overlapping, which is not the best result, but it is primarily due to the elimination of some activities which were not in the critical path. However, this result is of lesser importance.

\section{CONCLUSIONS}

Maintenance is one of the fundamental pillars of Lean Production. It's importance is often neglected, but it becomes obvious that breakdowns and stoppages are against any logic of continuous flow, waste reduction and reduced inventory levels. Some final thoughts an highlights:

1) Maintain equipment efficiently. Do not overservice.

2) Train all personnel in the importance and execution of maintenance routines (TPM).

3) Standardize all maintenance operations, for production and maintenance personnel.
4) Eliminate problems at their root cause(s). Too often, maintenance is done at the symptom level, not the root.

5) Manter bases de dados e analisá-las. Só através de uma análise cuidada de dados dos equipamentos pode a manutenção desenvolver acções eficazes de manutenção preventiva.

6) Maintain and analyze data. Only through statistical and detailed analysis can it be possible to identify priorities and act in them.

7) Motivate and involve maintenance personnel in continuous improvement activities, in order to reduce time and cost.

8) Make sure all levels in the organization are taken into consideration when changes are decided upon, which affect the day-to-day work of shop floor personnel.

The application of the abovementioned guidelines to the substitution of an electric motor clearly shows the wide applicability of Lean methods to identify and eliminate waste, even in specific maintenance activities. Never compromising the quality of the maintenance service, it is important, in a globally competitive environment, that cost and time are minimized, through the continuous identification and reduction/ elimination of all non-value adding activities.

\section{REFERENCES}

[1] Taichii Ohno, Norman Bodek, "Toyota Production System”, Productivity Press, 1988.

[2] Taichii Ohno, “Gemba Keiei”, JMA Management Center Inc., 1982.

[3] J.P. Womack, D.T. Jones, "Lean Thinking", Free Press, 2003.

[4] K. Arai, K. Sekine, "TPM for the Lean Factory: Innovative Methods and Worksheets for Equipment Management", Productivity Press, 1998.

[5] "Job Methods - Sessions outline and reference manual", Training Within Industry Service, War Manpower Commission, 1943.

[6] [6] S. Shingo, "Quick Changeover for Operators: The SMED System", Productivity Inc. 1996. 